\title{
Exploring the Socio-cultural Context of Dowry Practice in Bangladesh
}

\author{
Neaz Ahmed", Abul Kashem \\ Department of Social Work, Shahjalal University of Science and Technology, Sylhet-3114, Bangladesh
}

Copyright $@ 2015$ Horizon Research Publishing All rights reserved.

\begin{abstract}
This paper focuses on socio-cultural context of dowry practice in Sylhet city of Bangladesh. By using qualitative methods twenty one dowry victims were selected purposively from three prominent organizations working with victims of dowry. In-depth interview schedule was used as a tool of data collection. Dowry is one of the most common forms of gender based discrimination in Bangladesh. Every year thousands of women used to face serious social, psychological and physical torture due to dowry related dispute. Even though they become the victim of acid violence; sometime some are killed by their husband and their in-laws. But practice of dowry is not similar in all the region of the country due to social, economic and cultural conditions. People are very likely to see it as a custom rather than an offence. Due to fear of losing social status, ignorance, improper or no idea about legal procedure and conservative social attitude they are less interested in seeking legal steps against their husbands and in-laws.
\end{abstract}

Keywords Dowry, In-laws, Culture, Oppression, Torture

\section{Introduction}

Bangladesh is a country of geographical and cultural diversity where different groups of people including nearly 50 sub-nations have been living together maintaining their own tradition and culture along with religious practices. Thus the country is composition of multicultural significance. Bangladesh has a large number of populations, more than 16 cores, among whom 49 percent is female (www.indexmundi.com/bangladesh). Though officially marriage age for female is 18 and 21years for male, but 48 per cent got married between 15-19 years (UNFPA, 2010). Like many societies of the world, in Bangladesh various social, cultural and economic problems often disharmonize not only national development, but also destroy personal life. In some extent, many social problems are closely linked to gender based discrimination, like dowry. Dowry is seen one of the most crucial social problems in Bangladesh which has wide range of impact over the society, especially brutal to women. It is something unethical and unsocial that people use as a weapon against other family when they get agreed to be related. It is estimated that one-third of the population live below the poverty line and unable to manage two meals per day. This poverty-ridden portion is almost rootless, live in slums or in the open air, have no strong family bondage or responsibility. Society is still dominated by the male, and women are less empowered to take decision in case of marriage, divorce, property maintain etc. Weakness in marriage registration process, early marriage and polygamy is comparatively easy that is one of the root causes of dowry in Bangladesh.

Marriage among Muslim is civil and contractual, whereas it is sacramental and eternal for Hindus. The custom of dowry as prevalent in Bangladesh presents a typical dilemma for the 'universalism and cultural relativism' debate. Dowry is considered to be an ancient practice associated with the institution of marriage in Bangladesh, which in very broad terms involves the giving of gifts from the bride's side to the groom's side at the time of marriage. Generally it is a process of giving or receiving cash or valuable assets before, during or after the marriage happening. Legally (Article 2, Dowry Prohibition Act 1980) dowry is defined as an agreement or contract, or even a condition of giving or receiving any valuable security between the parties on which marriage is dependent.

Where dowry has disappeared in Europe, but it is still exist in Indian Sub-continent as the continuation of ancient marriage culture. Not only do they still exist but also it has been reported that these payments have been increasing since the 1950s (Caldwell, Reddy and Pat (1983), Rao (1993), and Billig (1992) for India. Lindenbaum (1981) analyses the evolution of marriage transactions over time in the Comilla district in Bangladesh from an anthropological point of view.) The first occurrence of the dowry practice (in South Asia) dates back approximately 2,000 years to Manu asserting stridhan (Arunachalam and Logan, 2006), which is distinguished from the modern dowry. Historical evidence shows that it has wide range of impact over social status and class. Among Hindu religion where social class and caste are very common and thus dowry has become socially and 
religiously approved (Rao, 1993; Dalmia and Lawrence, 2005), even it is seen as the religious structure (Government of India, 1974: 71). But in Bangladesh, where majority people are Muslim, it has become popular instead of bride price (pon) after independence (Rozario 2001:131-135, White 1992:102).

Different studies and theoretical explanations have attempted to correlate factors associate with dowry practice. In Bangladeshi society where patrilineal and patrilocal relationship with marriage and level of education of grooms (Arunachalam and Logan, 2006; Esteve-Volart, 2004) might have partial connection to dowry but recent progress in reducing gender based disparity and increasing rate of female education do not support it. Some argue that lowering women's access to agricultural activities due to mechanization (Kabeer, 1988), decrease in the economic role of women (Kishwar 1999: 23-24) or access of men to cash wages and land under colonial rule (Oldenburg, 2001) decreased their economic role and increased the demand of dowry. Demand and supply of grooms ('marriage squeeze' theories) (Goody, 1973; Murdock, 1967; Quale, 1988; Ambrus, 2008 ART 2; Geirbo and Imam, 2006 ART 6) and men earning capacity (Becker, 1981; Rao, 1993) supposed to dominating but the changing nature of women' economic activities and empowerment do not match this argument (Bangladesh Labor Force survey, 2010). White challenges theories like this by arguing that at the same time as dowry increases, the rate of women in paid labor increases (White1992:103).

Many authors viewed it as compensation for the absence of inheritance rights in their father's property for daughters (Gupta, 2003) where economists typically model dowries as the outcome of female competition for grooms (Becker, 1981; Rao, 1993; Edlund, 2000; Botticini and Siow, 2003); or due to transfers of resources clearing marriage markets (Becker, 1973; 1974). As education and urban employment were largely available to men, parents of grooms started to demand dowry as a reimbursement of their investment in their son (Rozario 2001:141-149). Like Rozario many authors blamed Hypergamy among Hindu and partially among Muslim also helps to sustain dowry practice (Das, 1975; Srinivas, 1984). Due to capitalism, newly rich families like to gain social status to make relationship with higher caste by giving dowry. Parents of potential brides knew that a good dowry was the way to secure the best groom, and hence contributed to the practice (Oldenburg, 2002). Taking the Oldenburg's analysis Siddiqi (2002) focuses on economic liberalization, growth of middle class and increased consumption as the factors associate with dowry practice. She explains how dowry is working as the instruments to escape poverty. Not only that, popular beliefs about grave consequences also needed to be considered here where urgency of daughter's marriage led parents to provide high rate of dowry. Rozario rightly pointed out that the shift from bride wealth to dowry has economic reasons, but that it was ideologies of purity and honor that sustained the practice

\section{(Rozario, 2004).}

Seeking better husband for daughter, gaining upper social status, property, power or whatever causes are directly or indirectly related to dowry practice in Bangladesh, but it's harsh and brutal effects and consequences are destroying public life. Despite having clear restriction upon dowry in Islam, people of Bangladesh are doing it without any judgment. Even law has failed to control and reduce it's impact over society, rather dowry related incidence has become common in our country. It is hardly possible to know how many women becomes the victim of dowry related violence because of inappropriate documentation and few incidents get media coverage or few of them filed case at the police station. Odhikar (2014) (a human rights NGO working in Bangladesh) has reported that at least 2797 women were killed from 2001 to mid of 2014 and another source (www.askbd.org) reported that 128 women were killed in 2013 (from January to September). Even many women are facing verbal and psychological abuse, become physically tortured or burnt by acid and a significant number of them committed suicide when they failed to tolerate brutal attack (Reports of ASK and Odhikar). The mentioned data are indicating the partial scenario but reality is more severe than we could imagine.

In Bangladesh, dowry amongst the majority Muslim population has increased in incidence and in monetary value in recent years (Amin and Huq, 2008), has become popular among the potential bride-grooms and for their families as a source of benefit. Not only among poor, illiterate or particular religion, dowry is fairly practicing in all segment of population. People have to bear huge economic burden as marriage cost is increasing (Rao, 1993). In many cases, dowry is practicing not only on the basis of demand or expression of love, rather educated people are doing it as social obligation to groom's family (Geirbo and Imam, 2006). In 293 life history interviews, Davis (2011) explored dowry payments and wedding expenses as one of three or four most damaging causes of decline in lives. But following the trend poor people are losing their valuable assets including land, livestock and indebtedness. Often dowry money was raised from a number of sources with money borrowed from relatives and NGOs and sometimes loans taken out were paid back by selling land or livestock.

Dowry is not only a practice with strong moral connotations in the public discourse. It has also acquired a symbolic position in the discourse about women's position in south Asian societies (Kishwar, 1999; Oldenburg, 2002). As it is practicing in generally by mass people in Bangladesh, so it is easy to understand that no specific models or theory is applicable to explain it. Its widespread use tells that people are habituated in this process as the part of marriage culture inherited from upper-class Hindus (Rozario, 2004).Along with cultural inheritance social exclusion and stigmatization of women has been bolstering this process (Tilly, 1999). Women are not facing discrimination, rather the most commonly harm is violence against or oppression of women 
(Srinivas, 1984; Bloch and Rao, 2002; Amin and Huq, 2008; Johnson and Naved, 2008). However, in addition to violence against, and oppression of women, dowry has another less obvious, but equally pernicious effects: for example, it is a major cause of impoverishment, both for men and for women. It was also evident that the impoverishment associated with dowry is likely to continue, and perhaps increase (Davis, 2011).

It would not be justice to blame the British Colonial role for it. Since the British role to present time, our society has been changing, getting new socio-cultural practices and life style, rate of education is accelerating, women are more independent and empowered, but dowry is still exists. Shifting from agro-economy to industrial economy has opened the doors for women to become earner, access to information and technology has created more opportunity to become aware and so many opportunities are here and there to get the services. Both in urban and rural areas, women are working like men, earning and managing family expenditure as necessary facing thousands of obstacles but they are still under threats. If we wished to draw a line between poverty and dowry, then obvious question is why do rich families are doing similar offence. Even it is not possible to draw a line between illiteracy and dowry as educated people also the part of dowry. So whatever the causes behind it's emergence, now it has become socially approved and culturally practiced marriage rituals. People are less interested in protesting against dowry; rather parents show deep interest in making a acceptable amount of dowry. Even in some cases, it is matter of prestige and showing economic strength and social status. Moreover, religion has less influence as it has been commonly practicing by the Muslims and Hindus living in this land.

Dowry has been the matter of concern to our policy makers, thinkers and researchers. There are several laws have enacted and different initiatives have taken so far. But changes are not satisfactory rather its diverse effects are always seen in our society. This practice is closely associated with the social, cultural and regional factors, so it is very important to find out the regional causes of dowry. Though Sylhet division has different social, economic and cultural ground in practicing dowry along with economic solvency and strength, thus the present study would be able to explore socio-cultural chemistry of dowry, and thus the policy makers would be benefited to take initiatives to remove this social curse.

\section{Methods and Materials}

With the objectives of an in-depth exploration on socio-cultural context of dowry practice in Sylhet city, the research project used a qualitative design. The Sylhet city was considered for the area of study. All married women with dowry victims living in the Sylhet City were regarded as the population of the study and from them twenty one (21) cases were selected purposively from three prominent organizations working for prevention of women oppression in Sylhet City namely Women Supports Program, BLAST and National Women Lawyers Association. Sample will be taking from those organizations. A standardized interview protocol was developed and applied to collect data from the participants. The protocol emphasized mainly open-ended questions covering all aspects of the research objectives. Corresponding questions was developed to explore the detailed information on issues such as nature of dowry, social and cultural factors and exploring cultural challenges to reduce the rate of dowry in Sylhet City. Data was collected by using unstructured interview guides and tape recorders. The collected data was organized, analyzed and interpreted following generally accepted principles and practices associated with qualitative research.

\section{Result and Discussion}

\section{Socio-demographic Information}

Among the respondents one has been found in Hindu religion. Out of twenty one five were found underage marriage. Most of their marriages were arranged by both the families. Only three were found with love marriage. One was found marriage with elopement. Their education background was very poor. Many of them were living separately after filling case with those organizations. Only six were found living at present with their husband. Those who live with their husband were older age and with children. Most of the respondents don't have child. The occupations of their husbands are mostly business, rickshaw pulling, MLSS job and other lower income group.

\section{Understanding and Opinion about Dowry}

There is a mix understanding about dowry among the respondents. They have not legal understanding about dowry but they know giving and receiving something at the time of marriage is called dowry. But all of the respondents opined that dowry is a bad social practice. Moreover they expressed that giving and receiving dowry is a criminal offence. There is no peace with or without giving dowry. If dowry is given initially, more dowries are demanded latter, and if not given problems are naturally occurred. One respondent opined

'Dowry is a social practice. At present there is no boy who gets married without dowry. Practice of dowry is a real threat to the society. Those who cannot give dowry, oppression in the form of physical torture remain in their personal life. My present condition is because of dowry'

Another respondent mentioned,

'Dowry is a social evil. Poor girls are usually victim of dowry. It has entered into our social life in every span. It is also a weapon of social oppression. Dowry is considered as disrespectfulness not only for the women but also for the man. Goods are being carried with the girls that are also disrespectfulness both for the bride and groom parties. 
Through this process girls are become the good of the society'.

Practice of Dowry is somewhat different in Sylhet region comparing with other parts of the country. Dowry is very much common in this region. Sometimes people regarded giving valuable articles not as a dowry but as a gift. In fact dowry is considered as a common task of marriage. It is also considered as a prestige of both the parties. One respondent stated:

In the custom of Sylhet region, dowry is closely associated with the prestige of the bride parties. Prestige becomes down of the bridge family when something is not given to the bridge. People consider dowry as a usual task of marriage. For the happiness of daughter, dowry is given. The articles, goods and ornaments that are given to the groom parties are used by the bride. So nothing is wrong to give dowry. If she remains in my house, she also uses those articles. In this regard, dowry is not considered as a bad practice'.

\section{One respondent stated}

'The surrounding people of the bride family criticise if valuable goods are not given at the time of marriage with the daughter. Even daughter are questioned by the groom family. Giving dowry has become a custom of the society. Dowry transition is more in this region. Someone can't arrange his daughter's marriage because of inability of giving dowry. Without dowry or insufficient dowry makes miserable conditions and women oppression after marriage. Dowry is considered as an integral part of marriage'.

There are many reasons while giving dowry. Those are considering the happiness of the daughter, upholding the prestige of the daughter's parents, lack of education and social awareness, personal economic gain of the groom. The groom thinks that if something takes from the bride family, my business establishment will be better. I will be able to go to the other countries. One respondent expressed in her opinion in this way,

I think the main reason of giving dowry is that the daughter's family think their daughter will remain happy in the groom's family with high prestige if dowry is sufficiently paid. Sometimes dowry is paid but not demanded. In my case at the time of marriage my father said 'Why should I not give something to my daughter's marriage. Should I send my daughter to the groom's family with empty hand". There is another reason of dowry. At the time of marriage both the relatives of the bride and groom discuss and also criticise about what articles are taken and given and how much cost of the articles that are taken from the father's family'

The process of dowry determinations and considerable factor are varied with respect to economic conditions, physical complexion of the bride and so on. Sometimes dowry is firstly initiated and demanded by the match maker and the final negotiation is made by both the families. In other times, dowry is firstly and lastly negotiated by both the families. In another dowry is simply demanded by the groom party. In little cases, dowry is negotiated parties comprising Ukil (negotiator of Marriage), older people of both the partied and opinion of bride and economic conditions of the bride family. In one case, dowry is initiated and demanded by the groom family and informing to the bride family. One respondent mentioned

'What are the valuable articles and when to be paid that are negotiated by sitting both the families. Generally furniture is counted as dowry at the time of marriage. But furniture is not considered as dowry in this region. If bride's family is well to do, dowry is more negotiated. On the other hand, if the girl is so dark, or ugly dowry is also more demanded and negotiated. It has become a rule that marriage means some valuable things should be given to the groom from the bride's family. In some cases dowry is negotiated by bargaining. But most of the cases it is negotiated and given by the situation demanded. In another dower money is also a factor of negotiating dowry. In my case when my uncle was demanded more dower money, then groom party was also demanded more dowry.'

One young dowry victim said

'Dowry is negotiated and settled by the demand of the groom and agreed upon by the ability of the bride's family. In some cases dowry is demanded after the marriage. In my case my husband demands 50 thousand take from my father's family. But I could bring only 10 thousand. Due to not bringing demanded money I was used to physical and mental torture on and often'.

There is a merit and demerits of dowry in our society. Many marriages are surviving smoothly due to proper dowry. Many marriages are in stake due to not paying dowry. If you can provide dowry as negotiated and even demanded after marriage, your daughter will remain well in the husband's family. If you cannot provide, the husband, and other in-laws will extend physical and mental torture over the daughter. There are some negative aspects of dowry. Those are: husband becomes greedy, delay of marriage among poor and middle class family, financial loss of those family, bad treatment from the societal people, ruin of rights of women, increases the oppression, economic oppression by the husband. Though dowry is given for the happiness of bright but the happiness may not continue for long time. When dowry money and other valuables are finished, then more dowry is demanded.

One respondent said,

'There is no positive side of dowry. The greediness of husband increases more if dowry is paid. The demand also increases afterwards and if not paid oppression comes to the wife's life. Sometimes dowry increases the status of newly married woman but that is temporary. Bride is good when good things can bring from the parents family but in future expectation also increases. The fact remained that the 
demerits of dowry is more. The family becomes financial crisis and in some cases landless in order to amassing money and other valuable articles. Because in many cases dowry to be paid in case of inability of the family'.

\section{Another dowry victim mentioned}

'I did not get any positive side of dowry in my life. Women are being tortured because of dowry. If dowry is paid little, different comments and arguments are usually faced by different people particularly from the in-laws. In another many girls are being died off due to dowry. Like many others parents, my parents become debt while giving dowry. My parents stated stop you, keep your mouth stop.' After getting dowry my husband started business.'

There is a mix opinion from the respondents and their parents about dowry. Initially parents argued that why should I give dowry. But unfortunately they have given dowry to their daughter marriage. But most of the respondents and their parents were against their dowry. They opined that dowry should be stopped. One respondent opined,

'I don't consider the dowry system. It is disrespect for a woman. I personally think system of dowry should be abolished. I brought dowry from my parents' family earlier. Now my husband demanded more dowries from my parents. But my parents are not in a position to give dowry. My parents also think dowry system should be abolished though they have given dowry in my marriage'.

There is a uniqueness of dowry in this region. Dowry is not only paid to the bride family to the groom but sometimes to be paid to groom family to the bride. The type of dowry is also different comparing to other parts of the country. The common types of dowry are furniture including cot, dining table, sofa etc. In fact all the household articles are included in dowry. Thought these things are not considered as dowry.. Money is usually less negotiated as a type of dowry. It is negotiated when girls are dark and ugly. Dowry is an integral part of marriage in this region whether poor or rich. That is the uniqueness of dowry in this region. One respondent stated,

'The unique feature of dowry in this region is that the rate and intensity of dowry is increasing day by day. Like a king of competition has been prevailing here. Sometimes parents leave them for competition. Who can give or receive more dowries? In one word, it goes to a miserable condition. Parents give more things as dowry so that others cannot say anything to their daughter. Many things are usually give to the daughter like furniture, almira, gold for the bride and also to the groom, electronic goods, pant, shirt, household chore, bedding and other essential articles for house management. Girls are forced to get dowry from the parents family for sending husband to the abroad, sending husband's brother to the abroad, and buying land.'

There are some responsibilities to reduce or stop dowry practice. Most of the respondent said they know the bad impact of dowry. They should inform others about the bad impact of dowry. The oppressed women due to dowry should be united and for a group for protect themselves. They also should inform to the elderly people about bad impact of dowry and motivate them not to give dowry.

One respondent stated,

'Personally I think very little can be done in this regard. As a girl I have very little to do. There is need to change the men's mentality. All oppressed should go to the court for proper judgement of dowry victim.. Government can take good initiative to stop dowry. Moreover it can be stopped only when others will be understood about the bad impact of dowry.. But I can assure you I will not take dowry for my sons and daughters marriage'.

One interesting respondent opined

'Personally I don't agree to stop dowry. My status in the in-laws family has been raised because of bringing dowry from my parents. We educated people don't also want that dowry should stop. I think if I was economically solvent my husband would not have kick out me with betting from his house due to dowry. There is a need of economic independence of women so that dowry cannot be demanded. There is also need of social movement in order to stop dowry.'

\section{Impact of Dowry on Personal Life}

The situation after demanding dowry is mostly hash, panic and as a result it creates physical, mental and social torture. Threat to divorce and sending to the father family are very much common situation if dowry is not properly fulfilled and paid. Verbal abuse is another form of oppression. Sometimes situation becomes volatile and other times cool if dowry can be brought from the in-laws. This situation prevails in case of dowry demanded after marriage. One respondent opined,

'He used to maintain good behaviour with me if I could bring the demanded money from my father' family. In case of not bringing money he could misbehave with me. He used to torture physically. My whole body is full of fracture. He keeps on saying he will divorce me if I could not bring the demanded money.'

\section{Another respondent stated}

'My husband and in-laws were not satisfied about dowry that was given with the ability of my family. They on and often sent me to my father's family to bring money. If fail they used to physically torture me. At last they force me to come to my father's family.'

One Hindu Woman stated her misery in this way

'My husband demanded five laces taka as dowry. Moreover every month my family has to pay money as monthly salary. My husband was main supporter about dowry with my in-laws family. Later on I was known that my husband has extra- marital relation with another girl. He 
was guided and supported by that woman. I inform to my father in-law about his son's extra marital affairs. In reply he informed me that 'I can get another girl for my son if she goes on but I will not get son if my son goes on'. They sent me to my family but did not return my ornaments that were given at the time of my marriage and my academic certificate also.'

\section{Another respondent stated}

'My husband used to physically torture me. I was severely sick for six days after being torture by my husband. My first baby was died by the torture of my husband when baby was in my womb. Now I am staying in my father's house. My husband is an addict and a pick pocket. Others are now saying he has an extra-marital relation with another girl'.

Women oppression due dowry is very much common not only to the poor family but too some extend middle class and too little extend to the upper class family. Most of the family has nothing to do. Family can go to the court for punishment of the husband and other associate but it has demerit. Many families in our society simply tolerate the oppression made by the husband but to keep their family intact. Girls in most cases share their miserable life with their paternal family. In some cases they fill case against their husbands. But in other cases, after the demand of future dowry some initiatives were made by the concerned relatives, members and chairmen of the concerned locality for solution the problems. But it was temporary. After sometimes, same oppression was started and forces to get back to the father's family. It can be said here that arbitration was made in some cases with a view to solve the dowry problem. Family support here is most important to even for their survival. As one respondent uttered,

'When I share everything with my parents' family, they extend their mental support to me. They said be patient, everything will be alright. Allah will see everything. Spend day and night, One day Allah will solve all problem. Then with their support I came here to fill a case against my husband'.

\section{Socialization of Dowry}

Dowry has become a custom according to the perceptive of the people of this region. In fact giving something to the groom at the time of marriage may not regard as dowry. They think it is given for the happiness of the daughter. Even there is no need to demand for dowry but dowry is given. In many cases demand may be shown from the groom family. And through this process, dowry has become a social customary form in marriage negotiation. One respondent said,

'Her village people think, giving dowry is a positive side. They give dowry for the happiness of their daughter. Some of the bride and their in-laws are considered dowry money and other valuable article as dignity of the bride and his family. They feel proud and keep on saying I got this and that in my marriage. Some say I will not get dowry and give dowry but unfortunately they give and take dowry. They say dowry is bad and should not practice but due to reality they take and give. Everybody consider dowry as a bad thing. But for the happiness of the daughter they give dowry at the time of the marriage. On the other hand, dowry was indirectly demanded from the bride family at the time of son's marriage.'

There is close relation between economic conditions and status of the family and dowry. If the groom family is poor, dowry is more negotiated from the bride family. Dowry money may consider as the establishment of the bride. On the other hand dowry is more negotiated among the rich family. They exchange money on their own will. Dowry is more when bride lives in abroad and bear higher caste. Some of the respondent said dowry has become usual because of rich people. On respondent opined

'Rich family makes our life miserable. They give more dowries so that it affect on our life. We remain in pressure. Groom family make example of others. They got many things but why should I not get. Those who are economically in a better position, they demand and give more dowries. Because of these rich people pressure keeps on the poor family. They give furniture and ornaments on their ability and will. As a result we become in pressure. There is a close relation even dowry with the family status. Respondent stated that you will arrange your daughter marriage with my son but dowry will be less that will not happen. How will I remain and see my face in the society? My family status is higher than your family status'.

\section{Cultural context of Dowry}

There is no religious obligation of dowry but the provision of dower is an essential part of Muslim marriage. According to Islam taking dowry is Haram (prohibited). Some of the respondent said they don't known about the Islamic provision of dowry. Half of respondents opined that Islam has prohibited the Dowry but nobody follows the rules of Islam. One respondent stated there is a provision of giving goods at the time of daughter marriage. Since the dowry is not culturally prohibited, it is expanding in our society day by day. It has become a habit of the society. It is increasing because of increasing demand of the people and nobody raise proper hand to prevent the culture of dowry. One respondent stated

'It is assumed that if huge amount of dowry is paid, daughter will be happy in the husband's house and her status will also be upgraded among the in-laws. Nobody will say anything. She will not be badly treated. Consequently dowry is associated with the social status of both the families that considered. The kinds of dowry are usually discussed among the concerned parties even by the surrounding people.'

\section{Another respondent said}

'Dowry is practicing year after years. One party is benefited in this system. In fact sometimes every family is 
benefited by this culture if family has both son and daughter. As a result society wants this culture be exist. Sometimes, daughter family encourage dowry more for getting provided boy. Due to this reason, dowry is prevailed and culturally accepted in our society. In patriarchal society, girls are less important than the boys. They are dependent mostly on their husbands. So dowry is given for the happiness of the bride and also the value of the husband. Close relatives, surrounding people and other associates may questions and discuss about the dowry. As a result dowry is culturally found in our society.'

Historically many original people of this region are already settled in particularly UK and working in other countries of the globe. Abroad groom and bride as well is valuable in case of marriage negotiation. The amount of dowry may very when groom is a citizen of UK. Dowry is sometimes paid by the groom family to the bride if bride is a citizen of the UK. Abroad brides and grooms are directly influencing the amount of the dowry for others people. Religious minded people also take dowry. They directly don't demand dowry but indirectly and using some gesture, they demanded dowry. There is a culturally change of dowry practice in this region. Nonetheless dowry is practicing and amount of dowry also increasing day by day.

Another respondent stated,

'Many things have been changed in dowry system in course of changing our time. A great change has been occurred in the amount of dowry. Dowry is more and kinds of valuable articles also being changed. Earlier dowry was settled by bargaining process. Now, this is not required. It has become a fix rule for both the parties. Bride party know these are the thing we have to give to the groom family. Side by side, newly innovated goods are added in the articles of dowry.

\section{Conclusions}

Dowry is very common in Bangladesh despite having specific legal provisions. Some are doing it without knowing the demerits and some view it as source of benefit. Some are habituated in this process following social trend and few view it as a matter of prestige. And in Sylhet region causes, factors and consequences are more or less different from others parts of the country and has been practicing this evil custom as an undividable part of marriage. Limitations of legal actions and services is one of the causes of dowry practice here, but major causes are deeply rooted in the social and cultural system those could not be changed only using laws. Rather massive social reform and action are urgently required to change their attitude and to bind them to rethink about the system. It is necessary to develop their level of awareness and understanding so that they could realize the negative aspects of such devil custom. Same time it is necessary to reform the existing legal provisions and process to make it more effective. As there are some special and exceptional causes and trend regarding dowry, so it necessary to consider those during developing polices, laws or action. As the project was limited among few respondents, so it was not possible for the researchers to draw a complete picture. So it is also necessary to introduce more and more research and investigation to understand the situation properly.

\section{REFERENCES}

[1] Annual Report, Ain O Salish Kendro (ASK), Dhaka, 2011.

[2] Amin, S. and Huq, L. (2008). „Marriage Considerations in Sending Girls to School in Bangladesh: Some Qualitative Evidence". Working Paper Series, No. 12, Population Council.

[3] Arunachalam R., and Logan, T.D. (2006) On the Heterogeneity of Dowry Movements.

[4] Cambridge: NBER Working Paper Series.

[5] Becker, Gary, A Treatise on the Family (Harvard University Press, Cambridge., 1981).

[6] Billig, Michael S. (1992), The Marriage Squeeze and the Rise of Groom-Price in

[7] India's Kerala State, Journal of Comparative and Family Studies, 23 (2)

[8] Botticini, Maristella and Aloysius Siow, "Why Dowries?," American Economic Review,93(2003), 1385-1398.

[9] Caldwell, John C., P. H. Reddy, and Pat Caldwell (1983), The Causes of Marriage

[10] Change in South India, Population Studies, 37 (3)

[11] Dalmia, Sonia, and Pareena G. Lawrence. 2005. "The Institution of Dowry in India: Why ItContinues to Prevail." Journal of Developing Areas, 38(2): 71-93.

[12] Das, Veena (1975) Marriage among Hindus. Devaki Jain. (FROM ART 5)

[13] Davis, Peter (2011). Social exclusion and adverse incorporation in rural Bangladesh: evidence from a mixed-methods study of poverty dynamics, Working Paper 28, Social Development Research Initiatives, Victoria Place, UK.

[14] Esteve-Volart, Berta. 2004. "Dowry in Rural Bangladesh: Participation as Insurance against Divorce." Unpublished paper. http://dept.econ. yorku.ca/\%7Eberta/dowry_web.pdf.

[15] Edlund, L. (2000). „The Marriage Squeeze Interpretation of Dowry Inflation: Comment". Journal of Political Economy 108(6), 1327-1333.

[16] Geirbo, Hanne Cecille and Imam, Nuzhat (2006). The Motivation Behind giving and Taking Dowry, Research Monograp Series 28, BRAC Research and Evaluation Division, Dhaka, Bangladesh.

[17] Goody, Jack. 1983. The Development of the Family and Marriage in Europe. Cambridge: Cambridge University 
Press.

[18] Human Rights Monitoring Report, Odhikar, Dhaka, 2012.

[19] INDIA, GOVERNMENT OF 1974, Towards Equality, Report of the Committee on the Status of Women in India. New Delhi: Department of Social Welfare.

[20] Johnston, H.B. and Naved, R.T. (2008). ,,Spousal Violence in Bangladesh: A Call for a Public-health Response" Journal of Health, Population and Nutrition, 26(3), pp. 366-377.

[21] Kabeer, Naila, "Subordination and Struggle: Women in Bangladesh," New Left Review I/168, March-April 1988.

[22] Kishwar M. Off the beaten track - rethinking gender justice for Indian women. New Delhi: Oxford University Press, 2002.

[23] Murdock, George P. 1967. Ethnographic Atlas. Pittsburgh: University of Pittsburgh.

[24] Oldenburg, VT. Dowry murder - the imperial origins of a cultural crime. New Delhi: Oxford University Press, 2002.

[25] Quale, Robina G. 1988. A History of Marriage Systems. New York: Greenwood Press.

[26] Rao, Vijayendra. 1993. "The Rising Price of Husbands: A
Hedonic Analysis of Dowry Increases in Rural India." Journal of Political Economy, 101(4): 666-77.

[27] Rao, Vijayendra, 'Dowry 'inflation' in rural India: A statistical investigation," Population Studies, 47 (1993a), 283-293.

[28] Rozario S. Purity and communal boundaries: women and social change in a Bangladeshi village. Dhaka: The University Press Limited, 2001.

[29] Siddiqi DM. Dowry: ancient custom or modern malaise? Dhaka: The Daily Star,19 February 2002.

[30] Srinivas, M.N. (1984). Some reflections on dowry. Delhi/London: Oxford University Press.

[31] The Dowry Prohibition Act 1980, Ministry of Law, Justice and Parliamentary Affairs, Government of Peoples' Republic of Bangladesh.

[32] Tilly, C. (1999). Durable Inequality. Los Angeles: University of California Press.

[33] White S. Arguing with the crocodile: class and gender hierarchies in a Bangladeshi village. Dhaka: University Press Limited, 1992.

[34] www.askbd.org 